\title{
Effect of sucrose concentrations on in vitro growth and subsequent acclimatization of the native bromeliad Vriesea inflata (Wawra) Wawra
}

\author{
Camila Freitas \\ Victória Carvalho \\ Catarina Carvalho Nievola * \\ Núcleo de Pesquisa em Plantas Ornamentais, Instituto de Botânica SMA/SP \\ Avenida Miguel Estéfano, 3687, Água Funda, CEP 04301-902, São Paulo - SP, Brasil \\ * Author for correspondence \\ ccnievola@uol.com.br
}

Submetido em 28/11/2014

Aceito para publicação em 16/06/2015

\section{Resumo}

Efeito de concentrações de sacarose sobre o crescimento in vitro e a aclimatização da bromélia nativa Vriesea inflata (Wawra) Wawra. O uso de sacarose é essencial para o crescimento de plantas in vitro, devido à fotossíntese reduzida nessa condição. Contudo, espécies epífitas ornamentais, que apresentam crescimento lento, têm mostrado melhor desenvolvimento em meios nutritivos com concentrações reduzidas desse carboidrato. Vriesea inflata (Wawra) Wawra é uma bromélia epífita nativa da Mata Atlântica de alto valor ornamental. O objetivo deste estudo foi avaliar os efeitos de diversas concentrações de sacarose no meio nutritivo sobre o crescimento in vitro e a posterior aclimatização em condições ex vitro. Plantas foram cultivadas in vitro em meio basal na ausência de carboidratos; e em meios contendo 1,$0 ; 1,5 ; 3,0 ; 4,5$ e $6,0 \%(\mathrm{p} / \mathrm{v})$ de sacarose por 60 dias. Posteriormente, as plantas foram aclimatizadas por 90 dias. Plantas cultivadas em concentrações acima de 3,0\% de sacarose tiveram o menor desenvolvimento depois de cultivo in vitro e aclimatização. No entanto, aquelas cultivadas em concentrações menores apresentaram o maior crescimento radicular in vitro, e originaram plantas maiores depois da aclimatização. Em média, 1,7\% de sacarose foi definida como adequada para cultivar $V$. inflata in vitro, para obter plantas mais vigorosas durante a aclimatização.

Palavras-chave: Bromeliaceae; Ex vitro; Fonte de carbono; Micropropagação; Ornamental

\section{Abstract}

Using sucrose is crucial for in vitro plant growth, due to decreased photosynthesis under this condition. However, ornamental epiphytic species, which have slow growth, have shown better development in nutrient media with low concentrations of this carbohydrate. Vriesea inflata (Wawra) Wawra is an epiphytic bromeliad native to the threatened Atlantic Rain Forest and it has a high ornamental value. This study aimed to evaluate the effects of various sucrose concentrations in the culture medium on in vitro growth and subsequent ex vitro acclimatization. Plants were cultured in vitro in basal media without carbohydrates; and in media containing 1.0; $1.5 ; 3.0 ; 4.5$; and $6.0 \%(\mathrm{w} / \mathrm{v})$ of sucrose for 60 days. After, plants were acclimatized for 90 days. Plants cultured in sucrose concentrations over $3.0 \%$ had the smallest development after in vitro culture and acclimatization. 
Nevertheless, those cultured at lower concentrations had the highest in vitro root growth, and they generated larger plants after acclimatization. On average, $1.7 \%$ sucrose was defined as appropriate to cultivate $V$. inflata in vitro, in order to obtain more vigorous plants during acclimatization.

Key words: Bromeliaceae; Carbon source; Ex vitro; Micropropagation; Ornamental

\section{Introduction}

The bromeliad Vriesea inflata (Wawra) Wawra is native to the threatened Atlantic Rain Forest, and it has morphological traits of high ornamental value (PEDROSO et al., 2010) (Figures 1a; 1b). This species and many other bromeliads are extracted from their original habitat to supply the ornamental trade, something which can pose a significant threat to the Bromeliaceae biodiversity (NUNES, 2002; NEGRELLE et al., 2012). Many in vitro culture protocols have been developed for bromeliad species to effectively propagate them, aiming both at conservation and commercialization (SILVA et al., 2012; SANTA-ROSA et al., 2013; KURITA et al., 2014).

The development of plants in vitro depends to a large extent on the supply of carbon sources in the culture media, since morphogenesis and growth are high energy requiring processes. However, the required carbohydrate concentration varies according to species, something which demands the definition of specific protocols (YASEEN et al., 2013). Sucrose is one of the more frequently used carbon sources on in vitro cultivation, where concentrations from 2 to $4 \%$ usually lead to optimal growth, as reported by Hazarika (2003). Accordingly, bromeliads are mostly cultured in vitro with $3 \%$ sucrose in the medium (DAL VESCO et al., 2011; CARVALHO et al., 2013; MARTINS et al., 2013).

Vriesea inflata has been propagated in vitro, as previously reported by our research group (PEDROSO et al., 2010). Studies report that the species have slow growth, even when cultured in vitro. Therefore, it is important to optimize the in vitro $V$. inflata growth in order to obtain vigorous plants that can acclimatize in a more effective way. It has been reported that lower concentrations of carbon sources in the culture medium can improve acclimatization (JO et al., 2009), which have been associated with higher photosynthetic ability (LANGFORD; WAINWRIGHT,
1987; HUYLENBROECK; DEBERGH, 1996). Lower sucrose concentrations in the nutrient medium were applied to other epiphytic bromeliads and high survival rates after acclimatization were obtained, as described for Vriesea gigantea Gaudich. (BENCKE; DROSTE, 2008) and Acanthostachys strobilacea (Schult. f.) Link, Klotzsch \& Otto (SANTOS et al., 2010).

This study aimed to evaluate the effects of various sucrose concentrations on in vitro and subsequent ex vitro $V$. inflata growth, in order to verify if lower concentrations improve the species' acclimatization.

\section{Material and Methods}

\section{Plant material}

Seeds of Vriesea inflata (Wawra) Wawra were collected from the "Alto da Serra de Paranapiacaba" Biological Reserve (Santo André, São Paulo, Brazil) (Figure 1a). They were surface-sterilized and aseptically transferred to $250 \mathrm{~mL}$ flasks containing $20 \mathrm{~mL}$ of modified Murashige and Skoog (1962) medium, according to Pedroso et al. (2010). The medium $\mathrm{pH}$ was adjusted to 5.8, followed by the addition of agar $\left(5 \mathrm{~g} . \mathrm{L}^{-1}\right)$ and autoclaving for $15 \mathrm{~min}$ at $121^{\circ} \mathrm{C}$. After autoclaving the media, seeds were placed in the flasks and maintained in a growth room at $25 \pm 2{ }^{\circ} \mathrm{C}$, with 12 $\mathrm{h}$ photoperiod and $30 \mu \mathrm{mol} . \mathrm{m}^{-2} \cdot \mathrm{s}^{-1}$ irradiance $\left(\right.$ Osram $^{\circledR}$ Fluorescent Lamps).

\section{In vitro culture at different sucrose concentrations}

One month after the seeds germinated (Figure 1c), 10 plants were transferred to each $250 \mathrm{~mL}$ flask containing $40 \mathrm{~mL}$ of basal media, without sucrose and supplemented with $1.0,1.5,3.0,4.5$ and $6.0 \%(\mathrm{w} / \mathrm{v})$ sucrose $\left(\right.$ Synth $\left.^{\circledR}\right)$. Flasks were kept in growth room under 
FIGURE 1: Vriesea inflata as seen in the natural environment, its ornamental use, and the stages of in vitro culture: a) adult plant located at the "Alto da Serra de Paranapiacaba" Biological Reserve; b) flowering plants in vases indicating ornamental value; c) 1-month-old in vitro seedlings (bar: $1 \mathrm{~cm}$ ); d) general aspect of 4-month-old in vitro plants after acclimatization for 60 days (bar: $2 \mathrm{~cm}$ ).
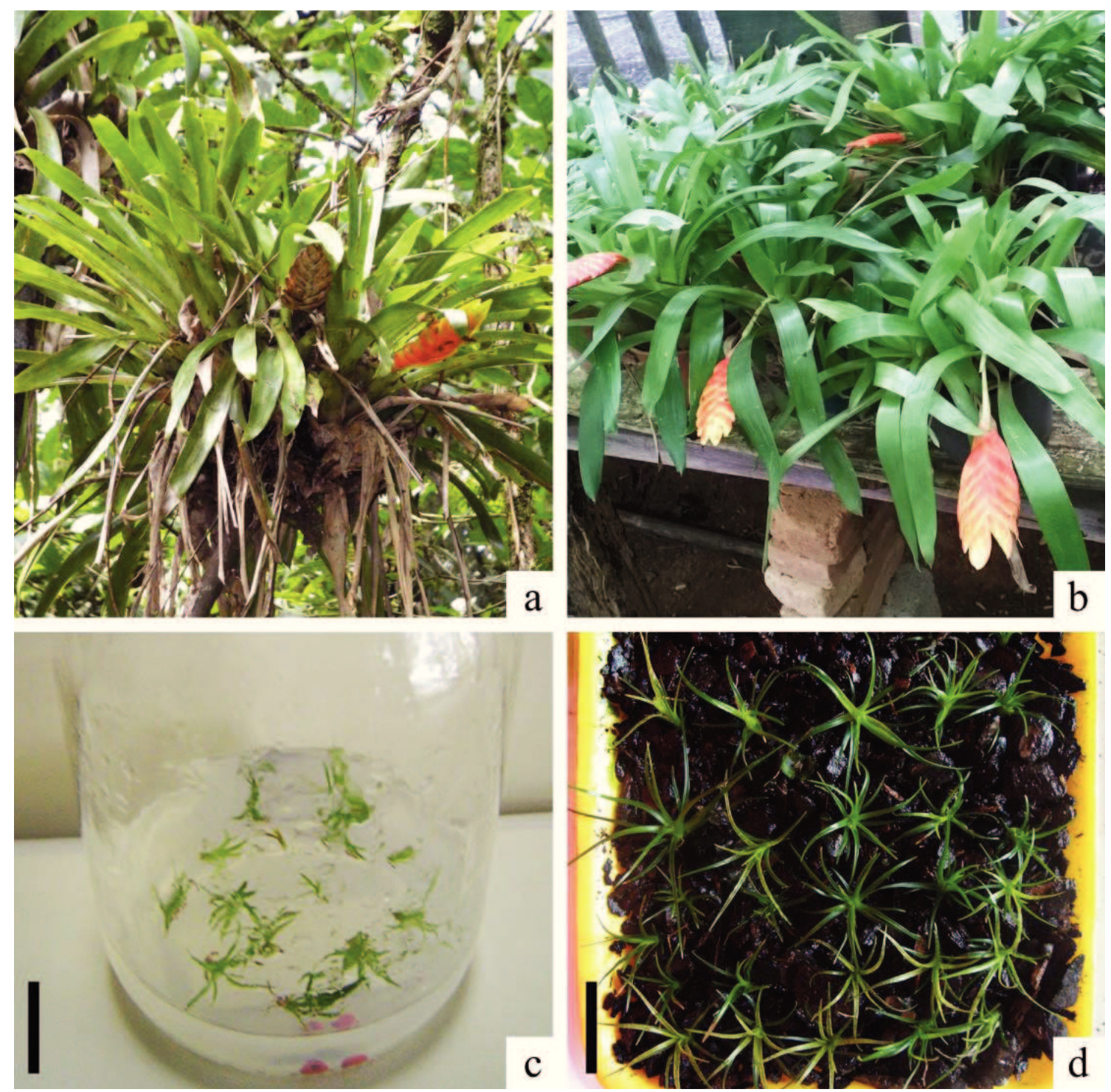

the same conditions described above. After 60 days of culture, 10 plants from each treatment were evaluated regarding the biometric features of survival rate, number of leaves and roots, length of the longest leaf and root, fresh and dry shoot mass.

\section{Ex vitro acclimatization}

After 60 days of culture under different sucrose concentrations, 10 additional seedlings from each treatment were transferred from the flasks to trays containing fine sterilized commercial medium-sized Pinus bark (100\%) (Figure 1d). Plants from each treatment were fertilized biweekly with $10 \mathrm{~mL}$ of a solution with $50 \%$ macronutrient salts as proposed by Murashige and Skoog (1962). Trays containing plants were kept in growth room under the same conditions cited above for 90 days, then plants were evaluated regarding the features described in the previous section. 


\section{Statistical analysis}

The experiments' design was completely randomized. For the in vitro culture and acclimatization experiment, the number of samples was 10 per treatment $(\mathrm{n}=10)$. Shoot mass was determined in triplicates (n $=3$ ). Data underwent analysis of variance, followed by regression analysis at $p<0.05$ by using the software SISVAR.

\section{Results and Discussion}

Vriesea inflata plants cultured in vitro without sucrose had low survival rates $(20 \%)$, perhaps because most plants could not photosynthesize in an effective way under this condition to generate energy for other metabolic processes (VON ARNOLD, 2008). However, varying sucrose concentration from 1.0 to $6.0 \%$ enabled total survival of $V$. inflata plants $(100 \%)$. Those treatments did not significantly influence the development of new leaves (Figure 2a). On the other hand, the number of roots, leaf and root length increased linearly with the reduction of sucrose in the medium, therefore, plants at $1.0 \%$ sucrose showed the highest mean values (Figure $2 \mathrm{a} ; 2 \mathrm{~b}$ ). Similar responses were noticed for banana and apple plants, where both had higher development when cultured at lower sucrose concentrations (< 3.0\%) (YASEEN et al., 2009; WAMAN et al., 2014).
Fresh and dry shoot mass showed a quadratic response to the varying concentrations, where plants kept at $1.0 \%$ sucrose also had the highest values (Figure $2 \mathrm{c}$ ). The alteration in $V$. inflata biometric features must derive from the influence sugars such as sucrose have on growth and development, because they have high nutritional value and control over many genes related to morphogenetic and metabolic processes $(\mathrm{KOCH}, 1996$; SOTIROPOULOS et al., 2006).

All plants cultured in vitro at $1.0-6.0 \%$ sucrose survived after ex vitro acclimatization (100\%). The varying sucrose concentrations had significant effects on all biometric characters of acclimatized plants, in which they showed a quadratic response (Figure 3). The maximum average of leaf and root growth were 1.6 and $1.5 \%$ sucrose, respectively, whereas plants from higher concentrations had smaller values (Figure $3 \mathrm{a} ; 3 \mathrm{~b})$. The results are in accordance with those observed before acclimatization (Figure 2). According to Rolland et al. (2006), carbon sources are essential for the production of growth hormones (auxins), which induce root development. However, the carbohydrate concentration required to produce auxins depends on the species. In fact, high sugar concentrations can lead to reduced osmotic potential in the media, resulting in lower availability of water for the plants, which in turn hampers growth (CALVETE et al., 2002; JO et al., 2009).

FIGURE 2: Regression analysis of biometric features of Vriesea inflata plants cultivated in vitro for 60 days under different sucrose concentrations in the nutrient media: a) number of leaves and roots; b) leaf and root length; c) fresh and dry shoot mass $(*: 5 \%$ significant $(p \leq 0.05))$.

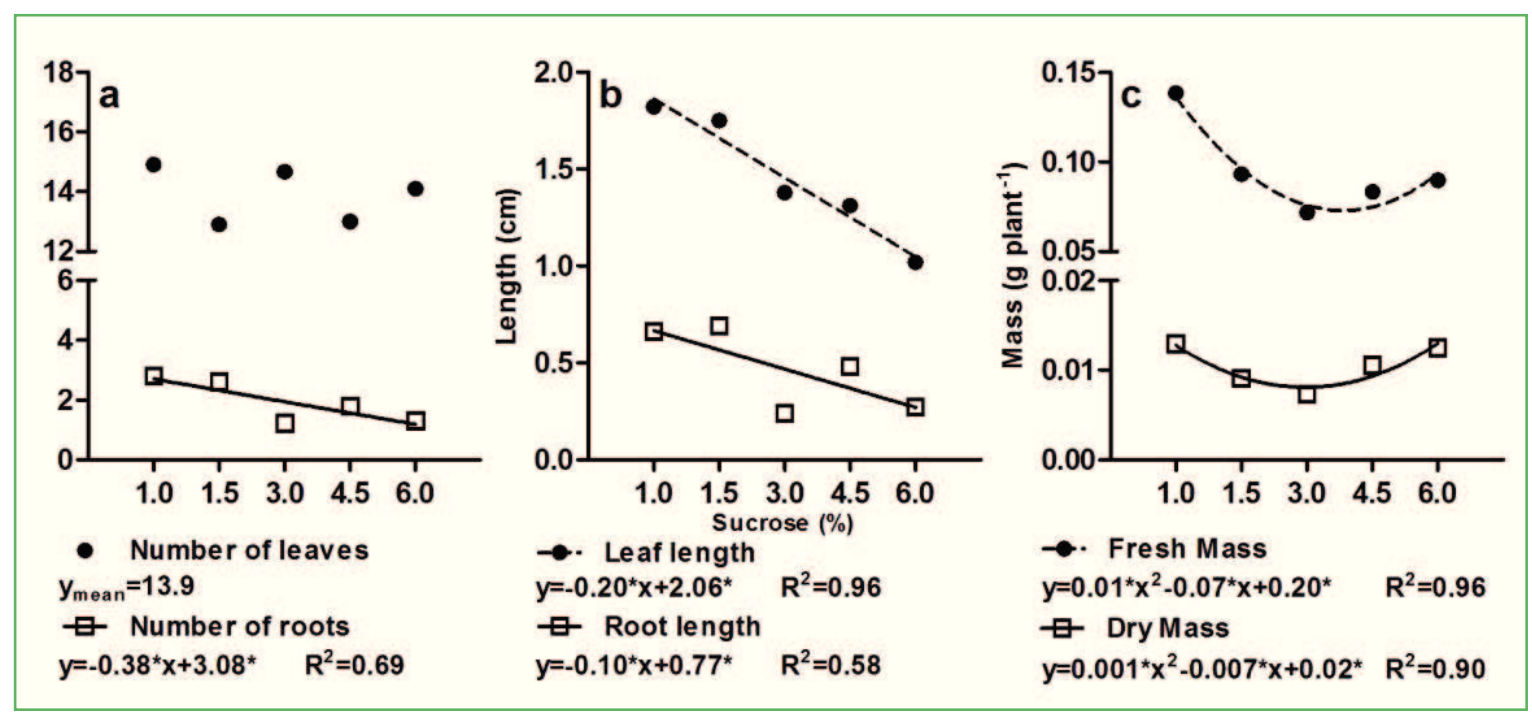


FIGURE 3: Regression analysis of biometric characters of Vriesea inflata plants acclimatized for 90 days after cultured in vitro for 60 days under different sucrose concentrations in the nutrient media: a) number of leaves and roots; b) leaf and root length; c) fresh and dry shoot mass (ns: not significant $(p>0.05)$, *: 5\% significant $(p \leq 0.05)$ ).

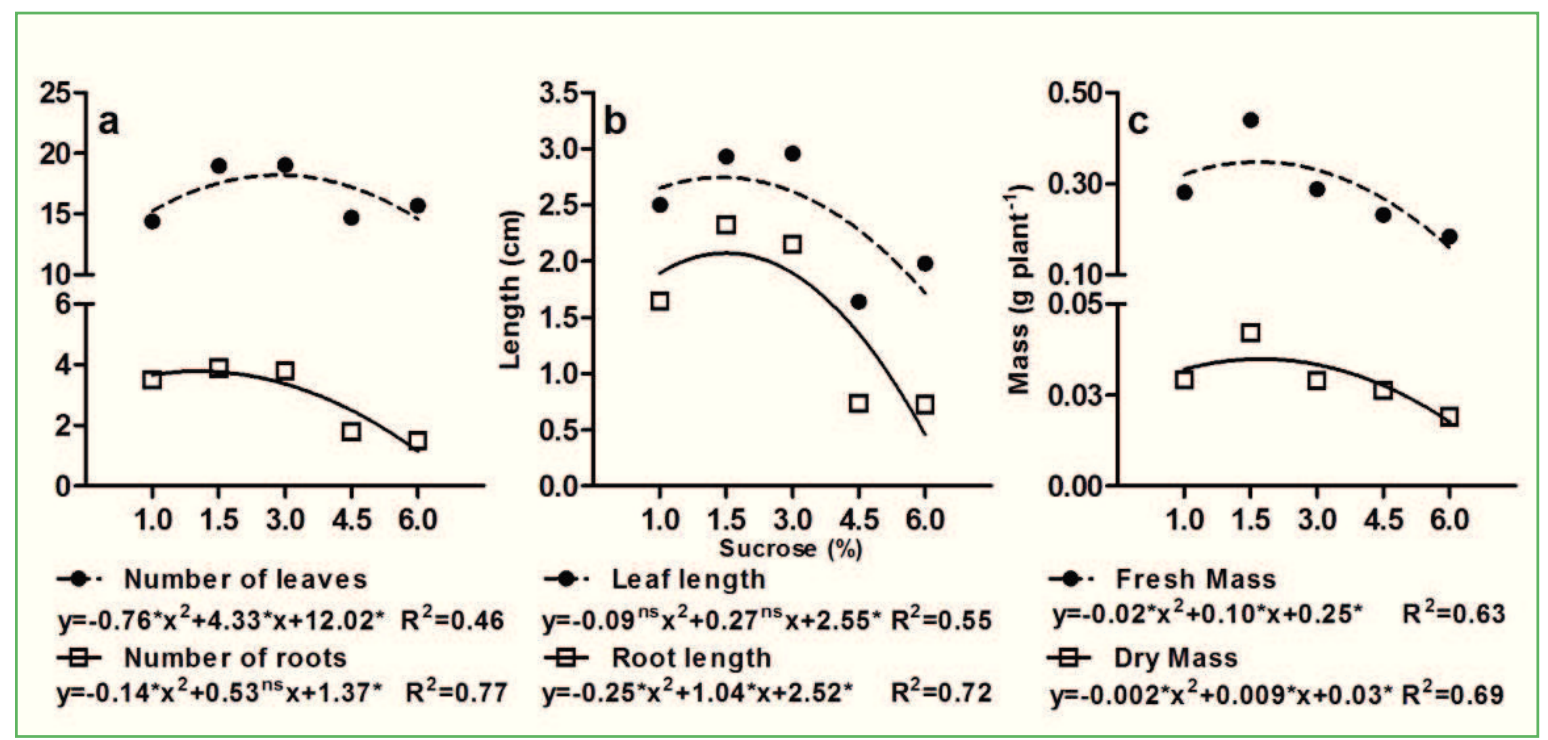

Fresh and dry mass of acclimatized plants were maximum at 1.9 and $1.7 \%$ sucrose, respectively (Figure $3 \mathrm{c}$ ), similar to leaf and root growth. In average, the maximum growth after acclimatization was observed in plants cultured in vitro at concentrations circa $1.7 \%$, something which suggests that such sucrose levels generate in vitro plants more adapted to grow under ex vitro conditions for longer periods. These results might be due to the significant root development observed in plants cultured in vitro under $3.0 \%$ sucrose (Figure 2a; 2b). Likewise, Galdiano Junior et al. (2013) noticed that cultivating the orchid Cattleya loddigesii Lindley under $2.0 \%$ sucrose effectively induced in vitro root growth, which resulted in higher survival after acclimatization in comparison with plants obtained from 3.0-4.0\% sucrose. Nievola and Mercier (1996) have shown that not only leaves but also roots of the bromeliad Vriesea fosteriana L.B. Sm., which can be found in epiphytic conditions, are important for nitrogen assimilation. Considering that $V$. inflata is also an epiphytic bromeliad, the best developed root system of plants obtained from $<3.0 \%$ sucrose concentrations may have led to a more effective nutrient assimilation, producing vigorous plants after acclimatization.

According to regression analysis, cultivating $V$. inflata plants in vitro at $1.7 \%$ sucrose for 60 days promotes significant root growth, which leads to more vigorous plants after 90 days of ex vitro acclimatization when compared to higher sucrose concentrations.

\section{References}

BENCKE, M.; DROSTE, A. Otimização da micropropagação de Vriesea gigantea Gaudich. (Bromeliaceae), uma espécie ameaçada de extinção, nativa do Rio Grande do Sul, Brasil. Pesquisas, Botânica, São Leopoldo, v. 59, p. 299-306, 2008.

CALVETE, E.; KÄMPF, A.; SUZIN, M. Concentração de sacarose no enraizamento in vitro de morangueiro. Horticultura Brasileira, Brasília, v. 20, n. 2, p. 186-191, 2002.

CARVALHO, C. P.; HAYASHI, A. H.; BRAGA, M. R.; NIEVOLA, C. C. Biochemical and anatomical responses related to the in vitro survival of the tropical bromeliad Nidularium minutum to low temperatures. Plant Physiology and Biochemistry, Paris, v. 71, p. 144-154, 2013.

DAL VESCO, L. L.; STEFENON, V. M.; WELTER, L. J.; SCHERER, R. F.; GUERRA, M. P. Induction and scale-up of Billbergia zebrina nodule cluster cultures: implications for mass propagation, improvement and conservation. Scientia Horticulturae, Amsterdam, v. 128, p. 515-522, 2011.

GALDIANO JUNIOR, R. F.; MANTOVANI, C.; FARIA, R. T. de; LEMOS, E. G. D. M. Concentrações de sacarose no desenvolvimento in vitro e na aclimatização de Cattleya loddigesii Lindley. Semina: Ciências Agrárias, Londrina, v. 34, n. 2, p. 583 $592,2013$.

HAZARIKA, B. Acclimatization of tissue-cultured plants. Current Science, Bangalore, v. 85, n. 12, p. 1704-1712, 2003. 
HUYLENBROECK, J. M.; DEBERGH, P. C. Impact of sugar concentration in vitro on photosynthesis and carbon metabolism during ex vitro acclimatization of Spathiphyllum plantlets. Physiologia Plantarum, Lund, v. 96, p. 298-304, 1996.

JO, E.; TEWARI, R. K.; HAHN, E.-J.; PAEK, K.-Y. In vitro sucrose concentration affects growth and acclimatization of Alocasia amazonica plantlets. Plant Cell, Tissue and Organ Culture, Dordrecht, v. 96, p. 307-315, 2009.

$\mathrm{KOCH}, \mathrm{K}$. E. Carbohydrate-modulated gene expression in plants. Annual Review of Plant Physiology and Plant Molecular Biology, Palo Alto, v. 47, p. 509-540, 1996.

KURITA, F. M. K.; MACHADO, B. D. M.; TEIXEIRA, N. B.; CÉSAR, C. G. DE A.; NIEVOLA, C. C.; TAMAKI, V. Fenologia, cultivo in vitro e aclimatização da bromélia ameaçada de extinção Nidularium minutum Mez. Biotemas, Florianópolis, v. 27, n. 1, p. 59-69, 2014.

LANGFORD, P. J.; WAINWRIGHT, H. Effect of sucrose concentration on the photosynthetic ability of rose shoots in vitro. Annals of Botany, London, v. 60, p. 633-640, 1987.

MARTINS, J. P.; SCHIMILDT, E. R.; ALEXANDRE, R. S.; SANTOS, B. R.; MAGEVSKI, G. C. Effect of synthetic auxins on in vitro and ex vitro bromeliad rooting. Pesquisa Agropecuária Tropical, Goiânia, v. 43, n. 2, p. 138-146, 2013.

MURASHIGE, T.; SKOOG, F. A revised medium for rapid growth and bio assays with tobacco tissue cultures. Physiologia Plantarum, Lund, v. 15, p. 473-497, 1962.

NEGRELlE, R. R. B.; ANACLETO, A.; MITCHELL, D. Bromeliad ornamental species: conservation issues and challenges related to commercialization. Acta Scientiarum. Biological Sciences, Maringá, v. 34, n. 1, p. 91-100, 2012.

NIEVOLA, C.; MERCIER, H. The importance of leaf and root systems in nitrate assimilation in Vriesea fosteriana. Bromélia, Rio de Janeiro, v. 3, n. 3, p. 14-18, 1996.

NUNES, J. V. C. Bromélias. In: SIMÕES, C. F.; LINO, C. F. (Ed.). Sustentável Mata Atlântica. São Paulo: Senac, 2002. p. 119-132.

PEDROSO, A.; LAZARINI, R.; TAMAKI, V.; NIEVOLA, C. C. In vitro culture at low temperature and ex vitro acclimatization of Vriesea inflata an ornamental bromeliad. Revista Brasileira de Botânica, São Paulo, v. 33, n. 3, p. 407-414, 2010.

ROLlAND, F.; BAENA-GONZALEZ, E.; SHEEN, J. Sugar sensing and signaling in plants: conserved and novel mechanisms. Annual Review of Plant Biology, Palo Alto, v. 57, p. 675-709, 2006.
SANTA-ROSA, S.; SOUZA, F.; VIDAL, Á. Micropropagation of the ornamental vulnerable bromeliads Aechmea blanchetiana and Aechmea distichantha. Horticultura Brasileira, Brasília, v. 31, n. 1, p. 112-118, 2013.

SANTOS, D. S. dos; TAMAKI, V.; NIEVOLA, C. C. In vitro propagation of the ornamental bromeliad Acanthostachys strobilacea (Schult. f.) Klotzsch via nodal segments. In vitro Cellular \& Developmental Biology - Plant, Dordrecht, v. 46, n. 6, p. 524-529, 2010.

SILVA, A.; COSTA, J.; ALCANTARA, G. B.; CARVALHO, D. C.; SCHUCK, M. R.; BIASI, L. A.; SCHEIDT, G. N.; SOCCOL, C. R. Micropropagation of Nidularium innocentii Lem. and Nidularium procerum Lindm (Bromeliaceae). Pakistan Journal of Botany, Karachi, v. 44, n. 3, p. 1095-1101, 2012.

SOTIROPOULOS, T. E.; MOLASSIOTIS, A. N.; MOUHTARIDOU, G. I.; PAPADAKIS, I.; DIMASSI, K. N.; THERIOS, I. N.; DIAMANTIDIS, G. Sucrose and sorbitol effects on shoot growth and proliferation in vitro, nutritional status and peroxidase and catalase isoenzymes of M9 and MM106 apple (Malus domestica Borkh.) rootstocks. European Journal of Horticultural Science, Stuttgart, v. 71, n. 3, p. 114119, 2006.

VON ARNOLD, S. Somatic embryogenesis. In: GEORGE, E. W.; HALL, M. A.; DE KLERK, G.-J. (Ed.). Plant propagation by tissue culture. 3. ed. Basingstoke: Springer, 2008. p. 335-354.

WAMAN, A. A.; BOHRA, P.; SATHYANARAYANA, B. N. Not all sugars are sweet for banana multiplication. In vitro multiplication, rooting, and acclimatization of banana as influenced by carbon source-concentration interactions. In vitro Cellular \& Developmental Biology - Plant, Dordrecht, v. 50, n. 5, p. 552560, 2014.

YASEEN, M.; AHMED, T.; ABBASI, N. A.; HAFIZ, I. A. In vitro shoot proliferation competence of apple rootstocks M. 9 and M. 26 on different carbon sources. Pakistan Journal of Botany, Karachi, v. 41, n. 4, p. 1781-1795, 2009.

YASEEN, M.; AHMAD, T.; SABLOK, G.; STANDARDI, A.; HAFIZ, I. A. Review: role of carbon sources for in vitro plant growth and development. Molecular Biology Reports, Farmington, v. 40, n. 4, p. 2837-2849, 2013. 